\title{
POLYCYCLIC AROMATIC HYDROCARBONS AND POLYCHLORINATED BIPHENYLS IN COASTAL ENVIRONMENTS OF VALDIVIA AND VALPARAÍSO, CHILE
}

\author{
HERNÁN PALMA-FLEMING ${ }^{1}$, CARLOS CORNEJO ${ }^{1}$, MYRIAM GONZÁLEZ $^{2}$, VIVIANA PÉREZ ${ }^{2}$, MARTA \\ GONZÁLEZ ${ }^{2}$, ELENA GUTIERREZ ${ }^{1}$, JOSÉ LUIS SERICANO ${ }^{3}$ AND MICHAEL SEEGER ${ }^{2}$
}

\author{
${ }^{1}$ Universidad Austral de Chile, Facultad de Ciencias, Instituto de Química, Casilla 567, Valdivia, Chile. \\ ${ }^{2}$ Laboratorio de Microbiología Molecular y Biotecnología Ambiental, Departamento de Química, Millennium Nucleus of Microbial Ecology and Environmental \\ Microbiology and Biotechnology, Universidad Técnica Federico Santa María, Valparaíso, Chile. \\ ${ }^{3}$ Geochemical \& Environmental Research Group, Texas A\&M University, 833 Graham Rd., College Station, TX 77845, U.S.A. \\ (Received: 10 July 2007 - Accepted: 18 January 2008)
}

\begin{abstract}
PAHs and PCBs were measured in the mussel Perumytilus purpuratus (Lamarck) collected from three different sites along the coast of Valdivia and Valparaiso, South-Central and Central Chile, respectively. Pollution at these sites is considered low with PAHs originating mainly from pyrolytic sources according to the Phenanthrene/Anthracene and Fluoranthene/Pyrene ratios. Temporal variation of PAHs was observed in Valdivia, while site variation was observed along the Valparaiso area. Total PAH concentrations in Valdivia ranged from $29.2 \mathrm{ng} / \mathrm{g}$ to $89.5 \mathrm{ng} / \mathrm{g}$ in 2001 and from $31.0 \mathrm{ng} / \mathrm{g}$ to $48.6 \mathrm{ng} / \mathrm{g}$ in $2002 \mathrm{while}$ in Valparaiso samples the total PAHs ranged from $27.3 \mathrm{ng} / \mathrm{g}$ to $253.1 \mathrm{ng} / \mathrm{g}$ and from $12.1 \mathrm{ng} / \mathrm{g}$ to $26.3 \mathrm{ng} / \mathrm{g}$ in 2001 and 2002, respectively. Polychlorinated biphenyls were not found in mussels from Valdivia; however five non-planar congeners were detected in samples from Valparaiso with total concentrations between $1.0 \mathrm{ng} / \mathrm{g}$ and $16.6 \mathrm{ng} / \mathrm{g}$ in 2001 and between $3.4 \mathrm{ng} / \mathrm{g}$ and $29.0 \mathrm{ng} / \mathrm{g}$ in 2002. The pesticide heptachlor epoxide was detected in all sampling sites of Valdivia during the years 2001-2002 at concentrations ranging between 1 and $3.5 \mathrm{ng} / \mathrm{g}$.
\end{abstract} Coast

Keywords: Perumytilus purpuratus, PAHs, PCBs, POPs, Marine Organisms, South-Central Chile, Central Chile, Contamination, Valdivia Coast, Valparaiso

\section{INTRODUCTION}

Persistent organic pollutants (POPs) are a wide class of semivolatile, toxic hydrophobic compounds which have been extensively used after World War II when thousands of chemicals were synthetized for many different applications. The industrial revolution and the actual global development have produced a worldwide massive production of POPs, whose emissions to the environment has become an issue of public concern. Their harmful presence in the ecosphere has been largely demonstrated by their toxicity to humans and many forms of terrestrial and aquatic life ${ }^{1}$. They show pro-carcinogenic or carcinogenic, endocrine disruption, neurotoxic, teratogenic activities in addition to several other deleterious effects upon exposure to animals, including humans $\mathrm{s}^{1-7}$. Biological conversion of POPs into products with increased toxicity, which is known from the bioactivation of xenobiotics in mammals, represents an additional serious health and environmental problem ${ }^{8,9}$. Due to their physicochemical properties POPs are transported long distances from the emission points and accumulated in different environmental compartiments ${ }^{1}$.

For the treatment of POP-contaminated environments, bioremediation is an important technology 10,11 , which has been applied successfully, for example, for the removal of petroleum ${ }^{12}$. Several efforts have been attained for legally-binding protocols to control, reduce, or eliminate discharges, emissions, and losses of persistent organic pollutants. One of these protocols is the Convention on Long-Range Transboundary Air Pollution (LRTAP) signed in June 1998 in Aarhus, Denmark, between U.S.A and Members of the United Nations Economic Commission for Europe (UN-ECE). Later, to address this global concern, 91 countries and the European Community signed a United Nations treaty in Stockholm, in May 2001. Under the treaty, known as the Stockholm Convention, the subscribed countries agreed to reduce or eliminate the production, use, and/or release of 12 key POPs, and additionally specify a scientific review process that could lead to the addition of other POPs chemicals of global concern. Recently, during 2004, Chile ratified the aforementioned Convention, giving the start for national track and inventory of the 12 POPs.

The U.S. Environmental Protection Agency (US EPA) has suggested a group of 16 PAHs as priority pollutants, but even though PAHs are not listed under the Stockholm Convention, actually there is enough scientific information about their adverse effects to the organisms to put this group on review process ${ }^{1,2,4,5,13}$. This group of POPs have their genesis from both natural and anthropogenic sources; however, those PAHs originated from petrogenic and pyrogenic sources are actually of special concern due to their uncontrolled emissions and ubiquitous presence in the environment ${ }^{1,14-16}$.

PCBs are one of the most widely distributed POPs in the environment that have a broad variability in their chemical physical properties ${ }^{1}$. The toxicity of some congeners is structure-dependent, where the most toxics are structural equivalents of 2,3,7,8-tetrachlorodibenzo-p-dioxin. Among the 209 possible PCB congeners, only 20 are non-ortho chlorine substituted like the planar congeners 77, 126 and 169, however they are less abundant in environmental compartments compared to the non-planar congeners ${ }^{17}$.

Bivalve mollusks have been extensively used as biomarker of pollution of persistent organic pollutants (POPs), mainly polycyclic aromatic hydrocarbons (PAHs), polychlorinated biphenyls (PCBs) and other hydrophobic compounds, because they tend to accumulate high levels of these pollutants mainly due to their inability to metabolize and to excrete them ${ }^{18}$. Due to their large $\log \mathrm{K}_{\mathrm{ow}}$ these compounds are readily absorbed and accumulated by marine organisms from polluted waters $7,19,20$. The accumulation of PAH and organochlorine compounds in bivalves is a consequence of an inefficient or complete absence of mixed-function oxidase (MFO) enzymes that use the cytochrome P-450 electron transfer system (CYP1A), a protein that plays a critical role in the oxidation of numerous xenobiotics ${ }^{2,5}$. The metabolism of PAHs by CYP1A yields to oxidized products with different levels of toxicity, resulting in deleterious effects on the organisms ${ }^{21}$.

Perumytilus purpuratus was selected as a suitable biomonitor to compare two different sites in Chile, Valdivia and Valparaiso, since it is a sessile organism showing a broad distribution along the Chilean coast ${ }^{22,23}$. This specie has been previously used to study heavy metal distribution ${ }^{24}$ and recently used for measuring polychlorinated biphenyls (PCBs) along the Chilean coast ${ }^{25}$.

Valdivia and Valparaiso sites represent two different environmental areas. The first one is located in south central Chile and sampling sites are in the proximity of the Corral Bay, where converge several rivers that comprise the Valdivia Estuarial System ( $\left.39^{\circ} 49^{\prime} \mathrm{S}, 73^{\circ} 18^{\prime} \mathrm{W}\right)$. This estuary is formed by two fluvial systems whose basins cover a total surface of $13,135 \mathrm{~km}^{2}$. Both systems come together close to the city of Valdivia and finally flow into the Corral Bay subdivided into two estuaries, Valdivia and Tornagaleones ${ }^{26}$. During the last fifteen years, the Corral Bay area has been subjected to an increasing anthropogenic impact mainly due to aerial emissions of numerous industries and whose liquid emissions are directly discharged into the rivers that comprise the Estuarial System. Valparaiso area is located in central Chile, and two of the sampling sites, Concon and Ventanas, are suspected of environmental impact by petroleum refinery, cooper refinery and thermoelectric industries. In addition, the sampling site in Concon is closely located to the outlet of Aconcagua River, which crosses important agricultural valleys. In this area, pesticides and heavy metals have been detected in fish two decades ago ${ }^{27}$. On the other side, Ventanas area is also impacted by harbor activities.

The aim of this study was to examine and compare the levels and origin of PAH and PCB pollution among two areas of different anthropogenic activities such as Valdivia and Valparaiso. Three sites are located along the coast of Valdivia, Playa Grande, San Ignacio, and Calfuco in front of the Corral Bay, 
South Central Chile and while the remaining sites Concon, Ventanas and Horcón are located in the Valparaiso area.

\section{EXPERIMENTAL}

All solvents used for extraction and clean-up procedures were nanograde quality (Merck). Glass distillation was used when solvent quality did not meet the requirement of purity specified by standard operation procedures (SOPs). Water of high purity grade, suitable for POP analysis, was obtained by elution through an ion exchange cartridge and then by boiling for 2 hours with nitrogen bubbling.

\section{Sampling}

Two campaigns were selected, May 2001 and July 2002 in Valdivia, XIV Region, at Playa Grande (39 $51^{\prime} 37^{\prime \prime} \mathrm{S}, 73^{\circ} 23^{\prime} 35^{\prime}$ 'W), San Ignacio

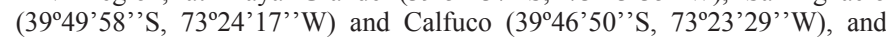
Valparaíso, V Region, at Concón (32 $55^{\circ} 06^{\prime}$ 'S, $\left.71^{\circ} 30^{\prime} 00^{\prime} \mathrm{W}\right)$, Ventanas

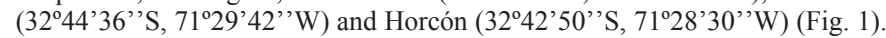
The sampling area was divided in three sectors separated by approximately 20 $25 \mathrm{~m}$ and triplicate samples were collected at each sampling station.

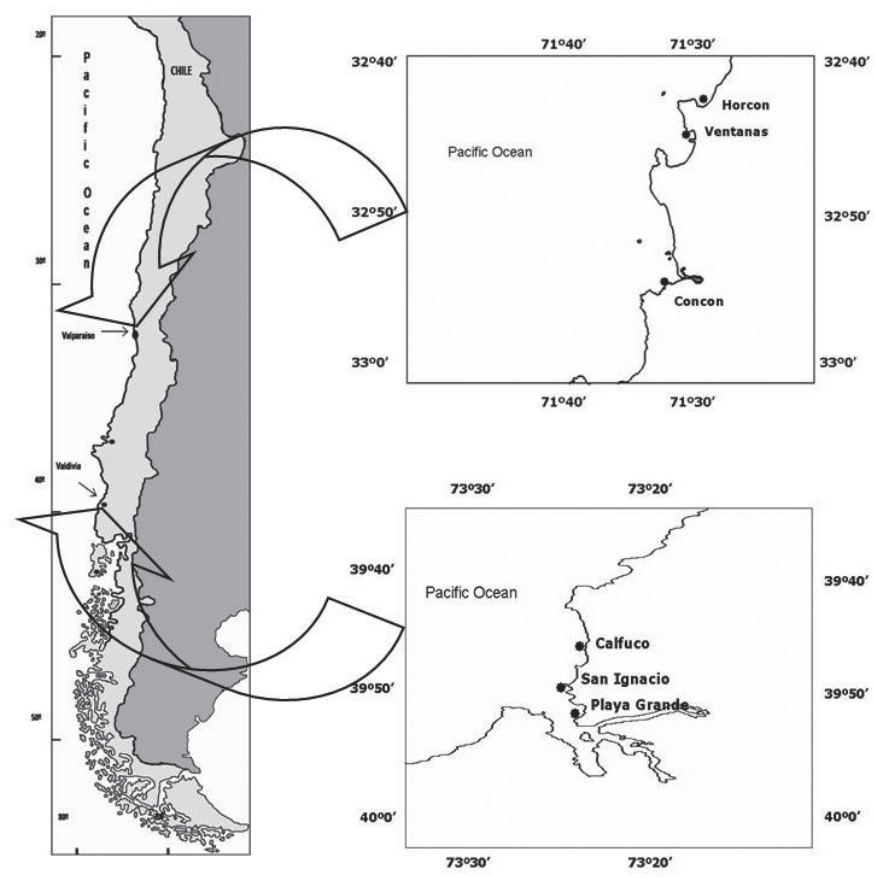

Fig. 1. Sampling sites: Valparaíso (Concon, Horcon and Ventanas); Valdivia (Playa Grande, San Ignacio and Calfuco)

Mussels were collected by hand in natural banks. Specimens were wrapped in aluminum foil and transported to the laboratory. Forty to fifty specimens were pooled for each triplicate sample, freeze-dried and stored frozen in glassamber flasks with Teflon lined caps until analysis.

\section{Sample Analysis}

a) PAHs

Samples were extracted according to the method described by Granby and Spliid (1995) ${ }^{28}$ and modified by the laboratory. Succintly, approximately 10 $\mathrm{g}$ of mussel homogenate dried with anhydrous sodium sulphate were soxhlet extracted with dicholoromethane after addition of perdeuterated PAHs used as internal standards (naphtahalene- $\mathrm{d} 8$, acenaphthene-d 10 , chrysene-d 12 and perylene-d12). After ca $8 \mathrm{hrs}$ (40 cycles), the extract was concentrated to 1 $\mathrm{mL}$ in a Kuderna-Danish apparatus. Then dichloromethane was exchanged by hexane and the crude extract was saponified by refluxing for $2 \mathrm{~h}$ with $50 \mathrm{~mL}$ ethanol/KOH $1 \mathrm{M}$ and then, the warm sample was transferred to a separatory funnel and $20 \mathrm{~mL}$ of $0.25 \mathrm{M}$ sulphuric acid was added. The neutralized aqueous solution was extracted three times with hexane and reduced to a volume of c.a. $1 \mathrm{~mL}$. The sample was further purified into aliphatic and aromatic fractions by alumina-silica gel column chromatography.
The aromatic fraction was analyzed by gas chromatography coupled to a mass selective detector (GC-MSD) as described by Palma-Fleming et al. 29. An HP 6890 PLUS gas chromatograph equipped with a programmable temperature vaporizing inlet (PTV) and coupled to an HP 5973 mass selective detector (Hewlett-Packard, Palo Alto, CA, USA) were used. The injector temperature was maintained at $280^{\circ} \mathrm{C}$ in a pulsed splitless mode. A GC program temperature ramp from $60^{\circ} \mathrm{C}$ for $4 \mathrm{~min}$. and then at a rate of $10^{\circ} \mathrm{C} / \mathrm{min}$. up to $300^{\circ} \mathrm{C}$ was used to afford the best separation of PAHs by using a capillary HP-5 MS column, $30 \mathrm{~m} \times 0.32 \mathrm{~mm}$ i.d. x $0.25 \mu \mathrm{m}$ film thickness (Hewlett-Packard, Palo Alto, CA, USA). The MSD was operated under Single Ion Monitoring mode (SIM). Naphthalene (N), acenaphthylene $(\mathrm{Ac})$, acenaphthene $(\mathrm{Acn})$, fluorene (Flu), phenanthrene $(\mathrm{P})$, anthracene $(\mathrm{A})$, fluoranthene (Fln), pyrene (Pyr), benzo[a]anthracene (BaA), chrysene (Chry), benzo[b]fluoranthene (Bbf), benzo[k]fluoranthene (Bkf), benzo[a]pyrene (BaPy), indeno[1,2,3-cd]pyrene (IPy), dibenzo[a,h]anthracene (DahA) and benzo[ghi]perylene (BgPer) were quantified on a dry weight basis relative to perdeuterated PAHs added to the methylene chloride extracts. Unresolved peaks of benzo (k)- and (b)fluoranthenes are indicated as $\Sigma$ BF . Total PAHs correspond to the sum of the 16 parent compounds. Analytical protocols were validated by using certified mussel tissue SRM 2974 (NIST). The recoveries of PAHs were between $50 \%$ and $118 \%$. The Relative Percent Difference (RPD) for analytical duplicates were less than $25 \%$. Detection limits for PAHs were about $100 \mathrm{pg} / \mathrm{g}$ dry weight.

Principal Component Analysis were made for temporal and spatial variation of PAH data using Statgraphic Plus version 5.1 software (Statistical Graphic Corp.). All PAH data were total PAH normalized to compensate for skewed distribution and to avoid mathematical modeling to be dominated by high PAH concentrations.

b) PCBs

The extraction and clean up of PCB in the tissue of Perumytilus purpuratus were carried out as described by Granby and Spliid (1995) ${ }^{28}$ and modified by the laboratory. Briefly, $24 \mathrm{~g}$ of anhydrous sodium sulphate were added to $7 \mathrm{~g}$ of homogenized mussel sample followed by the addition of internal standard (tetrachloro $\mathrm{m}$-xilene) and then Soxhlet extracted with dichloromethane. After $8 \mathrm{~h}$ (40 cycles), the extract was concentrated, solvent exchanged by hexane and then clean-up was carried out in columns of $\mathrm{Al}_{2} \mathrm{O}_{3}$ and $\mathrm{SiO}_{2}$. Sulphuric acid was added to the concentrated extract previous to the $\mathrm{SiO}_{2}$ column clean-up. The extract was transferred to an amber vial and then concentrated to c.a. $1 \mathrm{~mL}$ under nitrogen stream.

A Fisons gas chromatograph GC 8000 Series coupled to a Fisons Trio 1000 Mass Spectrometer operated in Negative Chemical Ionization mode (NCI) were used for sample analysis as described by Chaler et al. ${ }^{30}$. A capillary column of $30 \mathrm{~m} \times 0.32 \mathrm{~mm}$ i.d., 0.25 film tic (BPX5, Supelco) was used at a temperature programmed mode from $140^{\circ} \mathrm{C}\left(2 \mathrm{~min}\right.$.) to $220^{\circ} \mathrm{C}$ at a rate of $5^{\circ} \mathrm{C} / \mathrm{min}$, then at $250{ }^{\circ} \mathrm{C}$ to $300{ }^{\circ} \mathrm{C}(20 \mathrm{~min}$. $)$ at a rate of $2{ }^{\circ} \mathrm{C} / \mathrm{min}$., carrier gas helium, methane as reactive gas, ion source temperature $180^{\circ} \mathrm{C}$ and injector temperature $239^{\circ} \mathrm{C}$. Internal standard addition solutions of $4,4^{\prime}$-dibr omooctafluorbiphenyl, 2,2',4,5',6-pentachlorobiphenyl and 2,2',3,3',4,5,5',6octachlorobiphenyl were used to quantify PCB.

\section{RESULTS AND DISCUSSION}

During 2001, the highest concentration of total PAHs of P. purpuratus from Valdivia was found in San Ignacio $(89.5 \mathrm{ng} / \mathrm{g})$, following Playa Grande $(73.4 \mathrm{ng} / \mathrm{g})$ and then Calfuco $(29.2 \mathrm{ng} / \mathrm{g})$, a site that is approximately $8 \mathrm{Km}$. away from San Ignacio. However, during 2002 Calfuco and San Ignacio had similar levels of total PAHs concentration $(48.6 \mathrm{ng} / \mathrm{g}$ and $45.6 \mathrm{ng} / \mathrm{g}$ respectively), but Playa Grande was slightly lower $(31.0 \mathrm{ng} / \mathrm{g}$ ). (Table 1). In Valparaiso, during 2001, the highest concentration was found in Concon (253.1 $\mathrm{ng} / \mathrm{g}$ ), then Horcón (48.7 ng/g) and finally Ventanas (27.33 ng/g) (Table 2). During 2002, the highest concentration was found in Concon $(26.3 \mathrm{ng} / \mathrm{g})$, while Horcon (12.3 ng/g) and Ventanas (12.1 ng/g) had similar total PAHs content. No PCBs were detected in samples collected in Valdivia area and only a few PCBs were detected in Valparaiso. Six congeners, PCBs 128, 137, 153, 170, 187 and an unidentified pentachlorobiphenyl are shown in Table 3. 
Table 1. PAHs in P. purpuratus (ng/g dw) of Calfuco (CC), Playa Grande (PG) and San Ignacio (SI) sites during 2001 and 2002. Average of triplicate samples and standard deviation are presented.

\begin{tabular}{|c|c|c|c|c|c|c|c|c|c|c|c|c|}
\hline & \multicolumn{2}{|c|}{ CC 2001} & \multicolumn{2}{|c|}{ CC 2002} & \multicolumn{2}{|c|}{ PG 2001} & \multicolumn{2}{|c|}{ PG 2002} & \multicolumn{2}{|c|}{ SI 2001} & \multicolumn{2}{|c|}{ SI 2002} \\
\hline & & $\mathrm{sd}$ & & $\mathrm{sd}$ & & $\mathrm{sd}$ & & $\mathrm{sd}$ & & $\mathrm{sd}$ & & sd \\
\hline Naphthalene & 0.21 & 0.04 & 0.11 & 0.15 & 0.29 & 0.26 & 0.23 & 0.07 & 0.19 & 0.10 & 0.12 & 0.06 \\
\hline Naphthalene 2-methyl & 1.97 & 0.40 & 0.66 & 0.82 & 3.45 & 3.72 & 2.00 & 0.68 & 2.66 & 1.06 & 1.77 & 0.81 \\
\hline Naphthalene 2,6 dimethyl & 0.47 & 0.40 & 0.37 & 0.26 & 0.40 & 0.12 & 0.27 & 0.22 & 0.56 & 0.05 & 0.23 & 0.03 \\
\hline Acenaphtylene & 0.48 & 0.36 & 0.28 & 0.03 & 0.87 & 0.05 & 0.18 & 0.02 & 0.62 & 0.20 & 0.31 & 0.22 \\
\hline Dibenzothiophene & 1.09 & 0.20 & 1.19 & 0.56 & 2.54 & 1.29 & 1.17 & 0.55 & 4.49 & 1.36 & 1.92 & 1.75 \\
\hline Phenanthrene & 4.40 & 0.20 & 8.50 & 0.70 & 23.20 & 2.10 & 4.40 & 0.80 & 16.70 & 5.30 & 14.70 & 15.70 \\
\hline Anthracene & 2.70 & 0.10 & 5.90 & 0.60 & 13.20 & 2.70 & 3.80 & 1.60 & 15.40 & 12.50 & 11.60 & 14.60 \\
\hline Phenanthrene 1-methyl & 0.54 & 0.05 & 0.46 & 0.10 & 1.89 & 0.68 & 0.32 & 0.21 & 4.95 & 3.65 & 1.42 & 1.31 \\
\hline Fluoranthene & 0.59 & 0.08 & 0.49 & 0.05 & 1.97 & 0.31 & 0.58 & 0.15 & 6.20 & 7.00 & 0.81 & 0.60 \\
\hline benzo[a]pyrene & 1.92 & 0.07 & 2.69 & 0.29 & 1.71 & 0.29 & 2.82 & 2.40 & 1.09 & 0.85 & 0.66 & 0.22 \\
\hline Perylene & 1.2 & 0.80 & 1.20 & 0.50 & 0.80 & 0.83 & 0.23 & 0.07 & 0.19 & 0.10 & 0.12 & 0.06 \\
\hline Indene[1,2,3-cd]pyrene & 1.18 & 0.87 & 11.14 & 18.86 & 1.92 & 1.48 & 7.42 & 9.91 & 6.27 & 4.33 & 6.84 & 2.83 \\
\hline Dibenzo[a,h]anthracene & 3.38 & 0.55 & 4.20 & 0.58 & 6.04 & 0.68 & 0.97 & 0.06 & 4.74 & 1.49 & 0.00 & nd \\
\hline Benzo[ghi]perylene & 1.94 & 0.32 & 1.94 & 0.73 & 5.71 & 0.95 & 0.53 & 0.22 & 4.49 & 2.11 & 0.74 & 0.64 \\
\hline Total PAHs & 29.15 & & 48.61 & & 73.42 & & 31.01 & & 89.50 & & 45.64 & \\
\hline $\mathrm{P} / \mathrm{A}$ & 1.6 & & 1.4 & & 1.8 & & 1.2 & & 1.1 & & 1.3 & \\
\hline Fln/Pyr & 0.5 & & 0.2 & & 1.1 & & 1.3 & & 0.4 & & 1.1 & \\
\hline
\end{tabular}

Table 2. PAHs in P. purpuratus (ng/g dw) of Concón (CO), Horcón (H) and Ventanas (V) sites during 2001 and 2002. Average of triplicate samples and standard deviation $(\mathrm{n}=3)$ are presented.

\begin{tabular}{|c|c|c|c|c|c|c|c|c|c|c|c|c|}
\hline & \multicolumn{2}{|c|}{ CO 2001} & \multicolumn{2}{|c|}{ CO 2002} & \multicolumn{2}{|c|}{ H 2001} & \multicolumn{2}{|c|}{ H 2002} & \multicolumn{2}{|c|}{ V 2001} & \multicolumn{2}{|c|}{ V 2002} \\
\hline & & $\mathrm{sd}$ & & sd & & $\mathrm{sd}$ & & sd & & sd & & sd. \\
\hline Naphthalene & 6.00 & 3.30 & 1.29 & 1.48 & 4.81 & 1.36 & 1.09 & 0.57 & 2.18 & 1.45 & 0.97 & 0.43 \\
\hline Naphthalene 2-methyl & 5.47 & 1.54 & 4.72 & 6.56 & 4.13 & 1.10 & 0.45 & 0.26 & 1.68 & 1.12 & 0.30 & 0.23 \\
\hline Naphthalene 2,6-dimethyl & 9.83 & 4.60 & 0.11 & 0.08 & 0.73 & 0.55 & 0.21 & 0.14 & 0.25 & 0.08 & 0.07 & 0.00 \\
\hline Acenaphtylene & 2.74 & 1.11 & 0.28 & 0.30 & 0.46 & 0.10 & 0.08 & 0.04 & 0.25 & 0.14 & 0.09 & 0.00 \\
\hline Dibenzothiophene & 29.12 & 9.34 & 0.89 & 1.13 & 3.45 & 1.07 & 0.51 & 0.19 & 1.01 & 0.40 & 0.40 & 0.37 \\
\hline Phenanthrene & 38.40 & 7.52 & 1.80 & 1.90 & 10.79 & 3.19 & 1.91 & 0.54 & 4.96 & 2.91 & 1.18 & 0.69 \\
\hline Anthracene & 3.00 & 1.51 & 0.76 & 0.69 & 9.67 & 3.19 & 1.00 & 0.29 & 3.68 & 1.95 & 0.96 & 0.82 \\
\hline Phenanthrene 1-methyl & 43.51 & 20.00 & 1.49 & 1.93 & 1.19 & 0.54 & 0.23 & 0.10 & 0.86 & 0.36 & 0.15 & 0.01 \\
\hline Fluoranthene & 7.28 & 1.57 & 0.49 & 0.51 & 0.71 & 0.39 & 0.40 & 0.05 & 0.54 & 0.36 & 0.16 & 0.06 \\
\hline benzo[a]pyrene & 3.41 & 2.56 & 1.41 & 1.16 & 0.80 & 0.36 & 0.54 & 0.20 & 0.82 & 0.38 & 1.11 & 0.23 \\
\hline Perylene & 2.60 & 2.17 & 0.50 & 0.40 & 1.01 & 0.03 & 1.61 & 0.00 & 0.39 & 0.03 & 0.87 & 0.29 \\
\hline Indene[1,2,3-cd]pyrene & 4.28 & 2.25 & 0.73 & 0.61 & 1.38 & 1.51 & 0.38 & 0.19 & 1.40 & 0.92 & 0.58 & 0.34 \\
\hline Dibenzo[a,h]anthracene & 7.63 & 3.88 & 1.31 & 1.18 & 2.46 & 2.45 & 0.73 & 0.30 & 2.70 & 0.67 & 1.26 & 0.19 \\
\hline Benzo[ghi]perylene & 5.76 & 2.92 & 1.48 & 1.02 & 1.36 & 1.16 & 0.42 & 0.26 & 2.01 & 0.95 & 1.11 & 0.71 \\
\hline Total PAHs & 253.07 & & 26.27 & & 48.87 & & 12.26 & & 27.33 & & 12.09 & \\
\hline $\mathrm{P} / \mathrm{A}$ & 12.8 & & 2.4 & & 1.1 & & 1.9 & & 1.3 & & 1.2 & \\
\hline Fln/Pyr & 0.2 & & 0.3 & & 0.6 & & 1.0 & & 0.9 & & 0.4 & \\
\hline
\end{tabular}


Table 3. PCB congeners (ng/g d.w.) in Perumytilus purpuratus of Valparaiso region during 2001 and 2002.

\begin{tabular}{|c|c|c|c|c|c|c|}
\hline \multirow{2}{*}{ PCBs } & \multicolumn{3}{|c|}{2001} & \multicolumn{3}{|c|}{2002} \\
\hline & $\mathrm{H}$ & $\mathrm{V}$ & $\mathrm{CO}$ & $\mathrm{H}$ & $\mathrm{V}$ & $\mathrm{CO}$ \\
\hline pentaCB & nd & $1.0^{* *}$ & 5.7 & nd & $3.0^{*}$ & 5.4 \\
\hline 2,2',3,3’,4,4'-hexaCB (PCB 128) & nd & 2.7 & 6.7 & $2.0^{*}$ & $10.0^{*}$ & $5.0^{*}$ \\
\hline 2,2',3,4,4',5-hexaCB (PCB 137) & nd & nd & nd & nd & $2.0^{*}$ & $2.0 * *$ \\
\hline 2,2',4,4',5,5'-hexaCB (PCB 153) & $1 *$ & 3.0 & 4.0 & $1.0^{*}$ & $11.0^{*}$ & $7.0 * *$ \\
\hline 2,2',3,3',4,4',5-heptaCB (PCB 170) & nd & nd & nd & nd & $1.0^{*}$ & nd \\
\hline 2,2',3,4',5,5',6-heptaCB (PCB 187) & nd & $1.0^{*}$ & nd & $0.4^{*}$ & $2.0 *$ & nd \\
\hline Total PCBs & 1 & 7.7 & 16.4 & 3.4 & 29.0 & 19.4 \\
\hline Total TEQ ${ }^{* * *}$ & 0.02 & 0.15 & 0.33 & 0.07 & 0.58 & 0.39 \\
\hline
\end{tabular}

* Value corresponding to a one replicate out of three field replicates

** Value corresponding to the average of two replicates out of three field replicates

*** TEQ $(\mathrm{pg} / \mathrm{g})=\Sigma\left([\mathrm{PCB}]_{\mathrm{i}} \cdot \mathrm{TEF}_{\mathrm{i}}\right) ; \mathrm{TEF}=0.001$ for mono-ortho substituted PCB; TEF $=0.00002$ for di-ortho-substituted PCB $(\mathrm{Safe}, 1992)^{45}$.

Total PCB concentration ranged from 1.0 to $16.4 \mathrm{ng} / \mathrm{g}$ d.w. during 2001 with Concon having the highest relative total PCB concentration, while in 2002, the concentration interval was between 3.4 and $29.00 \mathrm{ng} / \mathrm{g}$ d.w. with the highest concentration detected in Ventanas followed by Concon. Only in samples from Valdivia the pesticide heptachlor epoxide was detected at concentrations ranging between 1.0 and $3.5 \mathrm{ng} / \mathrm{g}$ during the years 2001-2002 (Table 4).

Table 4. Heptachlor epoxide (ng/g d.w.) in Perumytilus purpuratus of Valdivia region during 2001 and 2002.

\begin{tabular}{|c|c|c|}
\hline \multirow{2}{*}{ site } & 2001 & 2002 \\
\cline { 2 - 3 } & Heptachlor Epoxide & $\begin{array}{c}\text { Heptachlor } \\
\text { Epoxide }\end{array}$ \\
\hline Calfuco & $3.5^{* *}$ & 2.4 \\
\hline San Ignacio & $1.0 *$ & 2.6 \\
\hline Playa Grande & $1.0^{*}$ & 1.0 \\
\hline
\end{tabular}

* Value corresponding to one replicate out of three field replicates

** Value corresponding to the average of two replicates out of three field replicates

\section{PAHs}

No studies on PAHs in P. purpuratus have been reported previously in both areas, Valdivia and Valparaiso. The concentrations of total PAHs in this study (29-90 $\mathrm{ng} / \mathrm{g}$, in Valdivia, and 12-253 $\mathrm{ng} / \mathrm{g}$, in Valparaiso, on a two year period) are lower than PAHs reported in Mytilus chilensis collected from an inner area located to the south of the Corral Bay (138-877 ng/g during the period 19992000 , described as medium polluted by PAHs $)^{29}$ and represent values of low to moderate pollution levels according to Baumard et al (1998) criteria ${ }^{31}$. PAHs levels in the present study are also comparable to the lower-medium range of PAHs determined in the mussel Mytilus californianus collected from San Francisco Bay by Oros et al (2005) (21-1093 ng/g d.w.) ${ }^{32}$ and lower than the levels reported by Sericano et al. (1995) ${ }^{20}$ in bivalves collected from Punta Arenas (1600 ng/g d.w), South of Chile, and also considerable lower compared to the levels found in blue mussel, Mytilus trossulus from Arcachon Bay, France, a site of high contamination (4500-5000 ng/g d.w.) ${ }^{33}$.

Comparing among Valdivia sites, during 2001, San Ignacio $(89.5 \mathrm{ng} / \mathrm{g})$ and Playa Grande (73.4 ng/g) PAHs levels were about 2 to 3 times higher than Calfuco $(29.2 \mathrm{ng} / \mathrm{g})$. Playa Grande and San Ignacio are in the entrance of the Corral Bay, while Calfuco is a more exposed open sea area (Fig.1). However, during 2002, the three sampling stations presented similar concentrations, Playa Grande (31.0 ng/g), San Ignacio (45.6 ng/g) and Calfuco (48.6 ng/g). Temporal variations of PAHs in bivalves may be mainly due to the trapping-resuspension dynamic from different environmental compartments, where biological and physical process determine their bioavailability of the different linear and nonlinear PAHs components to aquatic organisms ${ }^{34-37}$. Perumytilus purpuratus are small mussels of approximately 1-2 cm. long whose habitats are rocky basis on coastal reef that are subjected to continuous air and water periodically interleaved exposure phases depending on tidal cycles. This is an additional condition that may influence the variation of xenobiotic bioconcentration of this specie. In this study, according to Baumard et al $(1998)^{34}$, the sites of Valdivia may be classified as a coastal area of low contamination by PAH.

In Valparaiso, the most contaminated site during 2001 was Concon (253.0 $\mathrm{ng} / \mathrm{g}$ ) however Horcón and Ventanas showed lower levels of PAH concentration (48.9 ng/g and $27.3 \mathrm{ng} / \mathrm{g}$ respectively). The 2002 sampling showed a more even distribution of PAH when comparing among sites. In general, Valparaiso may also be classified as a low contamination area by PAH, with the exception of Concon during 2001.

Correlation coefficients between individual PAH concentrations in Valdivia sites were found to below for most of the parent components and 1-methylphenanthrene, except for 1-methylnaphthalene, 2-methylnaphthalene and 2,6-dimethylnaphthalene $\left(\mathrm{r}^{2}>0.95\right)$ and according to this analysis no information can be drawn relative to whether the contamination was produced by the same sources or different sources of PAHs. On the other hand, molecular indices may be suggesting a pyrolytic rather than petrogenic imput, since the ratio $\mathrm{P} / \mathrm{A}$ is between 1 and 10 , although the ratio Fluo/Py is $<1$. Principal components analysis account for more than $70 \%$ of the variance in data from Valdivia and the scores plot divides the samples into two groups, showing seasonal variance instead of site variance (Fig. 2).

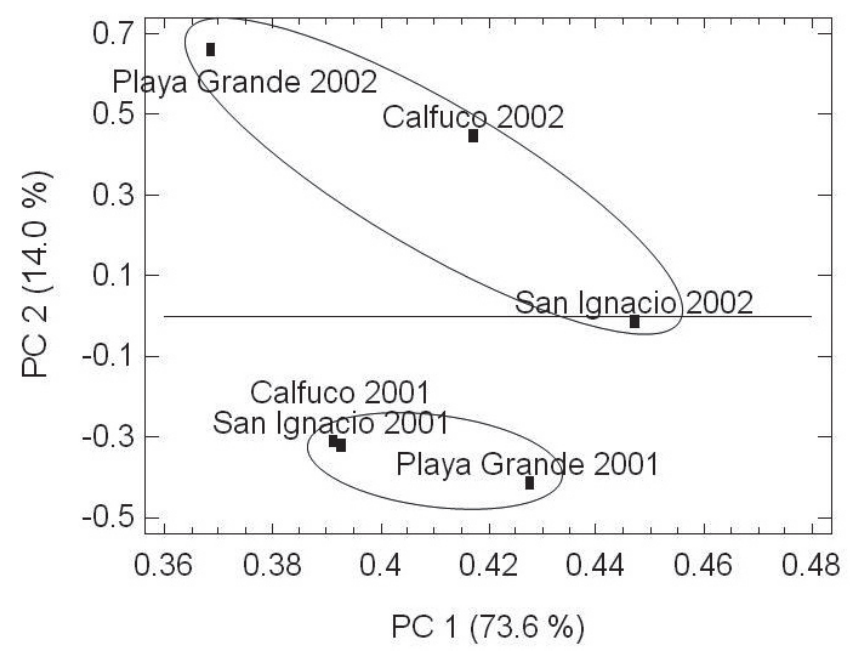

Fig. 2. Principal Components Analysis (PCA) of PAH in Perumytilus purpuratus of Calfuco, Playa Grande and San Ignacio, Valdivia region during the period 2001-2002.

Correlation coefficients between individual PAH concentration in Valparaiso sites showed medium to high values $\left(\mathrm{r}^{2}>0.80\right)$ for most of individual parent and methyl derivates PAH, indicating that contamination was probably 
produced by different sources, like in Valdivia. The high concentration of total PAH in Concon during 2001, a home of a petroleum refinery industry, may be due to a probable petroleum contamination, since showed a high P/A ratio $(\mathrm{P} / \mathrm{A}>12)$ and a low Fluo/Pyr ratio (Fluo/Pyr $<0.2)$. The high concentration of Benzothiophene in Concon during 2001 also suggest an anthropogenic imput since it has been shown in previous studies that this heterocyclic sulfur compound is suitable for monitoring oil pollution in the sea ${ }^{38,39}$. Ventanas is a home of a coal fuel thermoelectric power plant and a metal foundry and refinery, however according to molecular indices, source contamination may be due mainly to pirolytic and, in less extension, to petrogenic imputs because the ratio $\mathrm{P} / \mathrm{A}$ is low (around 1-2) and the ratio Fln/Pyr is $<1$. Principal Components Analysis (PCA) account for more than $50 \%$ of the variance in the data from Valparaiso and the scores plot clearly divides the samples into two groups. Site variance shows that Concon samples differ from Ventanas and Horcón (Fig. 3).

The molecular indices of PAH observed in samples of $P$. purpuratus from Valdivia and Valparaiso reveal the complexity of the mechanism that govern the PAHs distribution in bivalves as the bioavailability of these components to the organisms is a result of their physicochemical properties (e.g., water solubility, vapor pressure, molecular weight), physicochemical properties of the substrate (e.g., sandy or muddy sediments, rocks, organic matter), episodic intense seabed mixing and climate ${ }^{35,40}$. Upon absorption of the xenobiotics by the organisms, the pattern of PAHs composition (fingerprint) will depend fundamentally on the bioaccumulation and the fate through biochemical decomposition reactions (DNA binding interactions, metabolism) ${ }^{40}$ and do not necessarily reflect the original absorbed fraction (bioavailable portion).

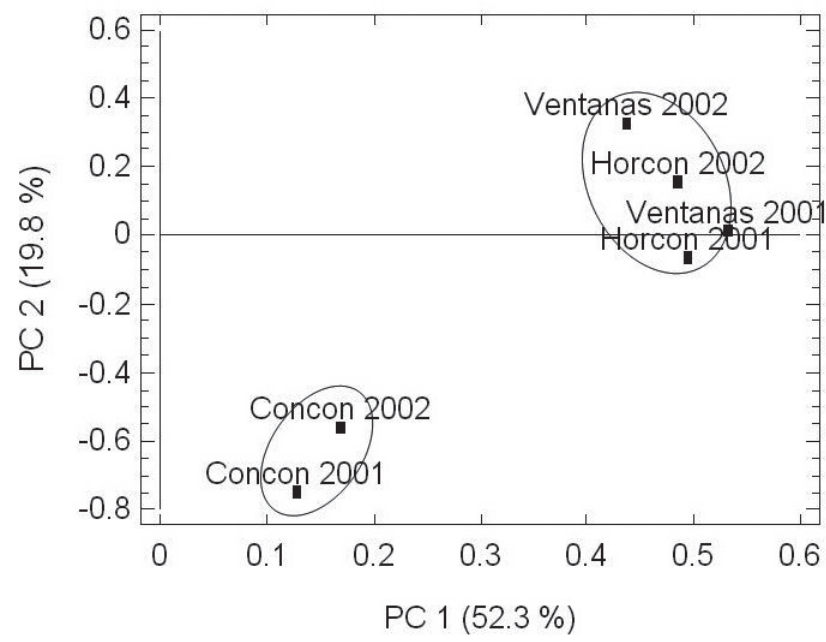

Fig. 3. Principal Components Analysis (PCA) of PAH in Perumytilus purpuratus of Concon, Ventanas and Horcon, Valparaiso region during the period 2001-2002.

Depuration process may operate not only to reduce the burden of total contaminants but also to change the relative concentration of each component. The lower molecular weight PAHs (2-3 rings) (the water-soluble portion) predominate over the higher molecular weight PAHs (four or more rings) in both sampling area, Valdivia and Valparaiso, which suggest that the main route for absorption of these xenobiotics by mussels is trough the gill, while those 5-6 member ring are mainly ingested through the digestive tract ${ }^{\text {? }}$.

Being Valdivia an area of high precipitation it may be expected that PAHs would be washed down to coastal sediments which constitute a good natural trap for hydrophobic compounds. Sources of pyrolitic PAHs could be the incomplete residencial and industrial wood, coal briquettes, charcoal and fuel combustion rounding 9-10 months/year. Some other possible sources of pyrolitic PAH would be the exhaust of outboard marine engines and airbone particle from terrestrial trafic emissions ${ }^{29}$. However, Valparaiso sites show two different areas with PAH having markedly distinct origin: those PAH coming from petroleum refinery at Concon, whereas those PAH encountered at Ventanas and Horcon locations seem to be of pyrolitic origin.

PCBs and pesticides

Only six PCBs congeners were detected in Valparaiso at concentrations ranging between 0.4 and $11.0 \mathrm{ng} / \mathrm{g}$ (Table 3). PCBs were not detected in Valdivia, and heptachlor epoxide was the only organochlorine compound detected. This pesticide was present in all sampling sites during the years 2001-2002 at concentrations ranging between 1.0 and $3.5 \mathrm{ng} / \mathrm{g}$. Total PCBs in Valparaiso ranged from $1.0 \mathrm{ng} / \mathrm{g}$ in Horcón to $29.00 \mathrm{ng} / \mathrm{g}$ in Ventanas during the period 2001-2002. The concentration levels in this study are in the lower range of PCBs found in the same specie by Sericano et al. (1995) ${ }^{41}$, under the "Mussel Watch Program", who reported high concentration levels of PCB in Arroyo Parejas (130 ng/g d.w.), and are also comparable to the lower range values reported by Mendoza et al. (2006) ${ }^{25}$ along the Chilean coast (8-298 ng/g d.w.). Both, Concon and Ventanas are petroleum refinery industrial areas that show higher concentrations of total PCB (range from $7.7 \mathrm{ng} / \mathrm{g}$ to $29.0 \mathrm{ng} / \mathrm{g}$ ) than the low urbanized and non-industrial Horcón area (range from $1.0 \mathrm{ng} / \mathrm{g}$ to $3.4 \mathrm{ng} / \mathrm{g}$ ) and these levels of concentration are comparable to the range of concentrations reported by Cheevaporn et al. (2004) ${ }^{42}$ in green mussel (Perna viride) and oyster (Crassostrea commercialis) in the East Coast of Thailand. It should be pointed out that the concentration levels of total PCB as well the fact that all congeners found in the present study do not represent a serious problem from the view of human and environmental health, because they can not attain planarity and therefore do not exhibit isostereomerism with the highly toxic dibenzo-p-dioxines ${ }^{43,44}$. However, although these congeners are less toxic than planar congeners, they are far more abundant in the environment. Five of the already identified congeners found in Valparaiso area are di-ortho-substituted (PCB 128, 137, 153, 170 and 187). According to the toxic equivalent factor (TEF) values for non-ortho substituted and di-ortho substituted PCB proposed by Safe ${ }^{45}$, the calculated analytical results based on toxic equivalents (TEQs) or TCDD (based on the 2,3,7,8-TCDD) shown in Table 3 reveal that samples from Ventanas and Concon are more toxic than those collected from Horcón, however all of them are less toxic than total PCB found in oysters from Galvestone and Tampa Bays ${ }^{44}$. The presence of high chlorine content (5-7 chlorine atoms) PCBs can be attributed to local industrial emissions along the coast of Valparaiso area, since they are less prone to travel long distances due to their high $\mathrm{K}_{\text {ow }}{ }^{46}$.

The only organochlorine compound found in Valdivia was heptachlor epoxide, a decomposition product of the pesticides heptachlor and chlordane which has been previously reported in other organisms of the Valdivia Estuarial System during 1994-1995 ${ }^{47}$. The concentrations of heptachlor epoxide in Perumytilus purpuratus found by the actual study are lower than those found in the estuary in Mytilus chilensis (c.a. $7 \mathrm{ng} / \mathrm{g}$ d.w.), but higher than the levels found in Choromytilus chorus (0.5 ng/g d.w.) during 1999 in Morro Gonzalo, located in the south coast of the Corral Bay ${ }^{48}$. The presence of this break down product in the environment can be explained considering that many other organochlorine compounds like PCBs and dioxins are recalcitrant and they remain in the environment, being detected long enough after they have been phased out. Commercial activities concerning to organochlorine pesticides in Chile, excluding lindane, has been prohibited since 1985, and the use of heptachlor was severely restricted under the Stockholm Convention. The toxicity toward to aquatic fauna and humans is well documented ${ }^{49}$, especially because $P$. purpuratus is used as non commercial food by fisherman and coastal population. EPA classified heptachlor epoxide as B2 - probable human carcinogen ${ }^{50}$

Although the screening results from Valdivia and Valparaiso are only snapshots of two consecutive years, these indicate that the levels of PAH contaminants were relatively low, while non-planar PCB contaminants were only detected in Valparaiso area at low concentration levels in the mussel Perumytilus purpuratus. The one year cycle 2001-2002 showed temporal variation in Valdivia but site variation was observed in Valparaiso for PAH. Further studies should be done to determine whether there exist tendency for bioaccumulation or natural depuration clean-up.

\section{ACKNOWLEDGEMENTS}

This study was supported by the following sponsors: Office of Research and Development of the Universidad Austral de Chile (Grant S-199903 and S-200511/DID-UACH), Universidad Técnica Federico Santa María (USM 130122, 130322 and 130522), Fondecyt 19908081020221 and 1070507 and Nucleo Milenio EMBA (MIDEPLAN, P04/007-F).

Thanks are given to Dr. Daisaku Ikeda, President of Soka Gakkai International, for his continuous guidance and support on the protection of the environment and human life. 


\section{REFERENCES}

1. R. Eisler in Handbook of Chemical Risk Assessment. Health Hazards to Humans, Plants and Animals. Polycyclic Aromatic Hydrocarbons, Vol. 2 Organics, Lewis Publishers, 2000; pp. 1500.

2. T. Shimada and Y. Fujii-Kuriyama, Cancer Science, 95, 1, (2004).

3. P. Goebell, C. Villanueva, A. Rettenmeir, H. Rubben. and M. Koveginas, World J. of Urology, 21, 424, (2004).

4. H. Van Gijssel, L. Schild, D. Watt, G. Wang, S. Dawsey, P. Albert, Y. Qiao, P. Tailor, Z. Dong and M. Poirier, Mutat. Res.-Fund. and Mol. Mech. of Mutagenesis, 547, 55, (2004).

5. G. Wogan, S. Hecht, J. Felton, A. Conney, and L. Loeb, Seminars in Cancer Biol. 14, 473, (2004).

6. F. Argemi, N. Cianni and A. Porta. Acta Bioquimica Clinica Latinoamericana, 39, 291, (2005).

7. P. De Maagd, D. Ten Hulscher, H. van den Heuvel, A. Opperhuizen and D. Sum. Environ. Toxicol. and Chem., 17, 251, (1998).

8. F. Oesch, F., and M. Arand in Toxicology. Xenobiotic metabolism. Marquardt, H., Schäfer, S.G., McClellan, R., and Welsch, F. eds. Academic Press, San Diego, CA., 1999; pp. 83-109.

9. B. Cámara, C. Herrera, M. González, E. Couve, B. Hofer and M. Seeger, Environ. Microbiol. 6, 842, (2004)

10. M. Alexander, Science 211, 132, (1981).

11. M. Seeger, K.N. Timmis, B. Hofer, Marine Chem. 58, 327, (1997).

12. J.R. Bragg, R.C. Prince, E.J. Harner and R.M. Atlas, Nature 368, 413, (1994).

13. A. Vyskocil, C. Viau and M. Camus, Human \& Experimental Toxicol. 23, $115,(2004)$

14. U.H. Yim, J.R. Oh, S.H. Hong, S.H. Lee and W.J. Shim, Environ. Forensic 3, 357, (2002).

15. L.C. Marr, T.W. Kirchstetter, R.A. Harley, A.H. Miguel, S.V. Hering and S.K. Hammond, Env. Sci. Technol. 33, 3091, (1999).

16. N.T.K. Oanh, L.B.Reutergard and N.T. Dung, Env. Sci. Technol. 33, 2703, (1999).

17. J.L. Sericano, S.H. Safe, T.L. Wade and J.M. Brooks, Environ. Toxicol. and Chem. 13, 1797, (1994).

18. D. Mackay and A. Fraser, Environ. Pollut. 110, 375, (2000).

19. S.M. Bartell, J.S. Lakind, J.A. Moore and P. Anderson, Int. J. Environment and Pollution 9, 3, (1998).

20. J.L. Sericano, T.L. Wade, A.M. El-Husseini and J.M. Brooks, Mar. Pollut. Bull. 24, 537, (1992).

21. J.J. Stegeman, M. Brouwer, R.T. DiGiulio, L. Forlin, B.A. Fowler, B.M Sanders and P.A. Van Veld in Biomarkers. Biochemical, Physiological, and Hystological Markers of Anthropogenic Stress, R.J. Huggett., R.A. Kimerle., P.M Mehrle and H.L.Bergman eds. Proceeding of the Eighth Pellston Workshop. Keystone Co., Boca Raton, Fl., Lewis Publishers, 1989; pp 235-236.

22. E. Lozada and P. Reyes, The Veliger 24, 147, (1981).

23. M. Thiel and N. Ullrich, Helgol. Mar. Res. 56, 21, (2002).

24. I. De Gregori, D. Delgado, H. Pinochet, N. Gras, M. Thieck, L. Muñoz, C. Bruhn and G. Navarrete, The Science of the Total Environ. 111, 201, (1992).
25. G. Mendoza, L. Gutierrez, K. Pozo-Gallardo, D. Fuentes-Ríos, M. Montory, R. Urrutia and R. Barra, Env. Sci. and Pollut. Res.13, 67, (2006).

26. M. Pino, G.M.E. Perillo, P. Santamarina, Estuarine, Coastal and Shelf Sci. 38, 201, (1998)

27. A. Ober, M. González, and L. Guerra. 1986. Contenido de pesticidas organoclorados y de metales pesados en el jurel (Trachurus murphyi) de la V Region. In La Pesca en Chile (Ed. Patricio Arana), Editorial Universitaria, Santiago, pp. 261-268.

28. K.Granby and N.H. Spliid, Mar.Pollut. Bull. 30, 74, (1995).

29. H. Palma-Fleming, J. Asencio, and E. Gutierrez, J. of Environ. Monit. 6, 229, (2004).

30. R. Chaler, R. Vilanova, M. Santiago-Silva, P. Fernadez, J.O. Grimalt, $J$. of Chromat. A 823, 73, (1998).

31. P. Baumard, H. Budzinski, P. Garrigues, Environ. Toxicol. Chem. 17, 765, (1998).

32. D.R. Oros and J.R.M. Ross, Mar. Environ. Res. 60, 466, (2005).

33. M.H. Devier, S. Augagneur, K. Le Menach, P. Mora, J.F. Narbonne and P. Garrigues, J. of Environ. Monit. 7, 224, (2005).

34. P. Baumard, H. Budzinski and P. Garrigues, Mar. Pollut. Bull. 36, 577, (1998).

35. K.M. Arzayus, R. M. Dickhut and E.A. Canuel, Org. Geochem. 33, 1759, (2002).

36. J. Tronczynski, C. Munschy, K. Heas-Moisan, N. Guiot, I. Truquet, N. Olivier, S. Men and A. Furaut, Aquatic Liv. Resour. 17, 243, (2004).

37. E. Francioni, A. Wagener, A.L. Scofield and B. Cavalier, Env. Forensics 6, 361, (2005).

38. G. Yang, X. Liu and J. Zhang, Environ. Pollut. 101, 405, (1998).

39. M. Ogata, K.Fujisawa, Bull. Environ, Contam. Toxicol. 44, 884, (1990).

40. B. Laffon, T. Rabade, E. Pasaro and J. Mendez, Environ. Internat. 32, $342,(2006)$.

41. J. Sericano, T. Wade, T. Jackson, J. Brooks, B. Tripp, J. Farrington, L Mee, J. Readman, J. Villeneuve, E. Goldberg, Mar. Pollut. Bull. 31, 214, (1995).

42. V. Cheevaporn, K. Duangkaew and N. Tangkrock-Olan, J. Health Sci. 51, $80,(2005)$.

43. J.Sericano, A. El-Husseini and T. Wade, Chemosphere, 23, 915, (1991).

44. J. Sericano, S. Safe, T. Wade and J. Brooks, Env. Toxicol. and Chem. 13, 1797, (1994).

45. S. Safe, Chemosphere 22, 61, (1992).

46. L. Guzzella, C. Roscioli, L. Vigano, M. Saha, SK. Sarkar, A. Bhattacharya, Environ. Int. 31, 523, (2005).

47. H. Palma Fleming, E. Alvarez. y E. Gutierrez, Bol. Soc. Chil Quim. 43, 201, (1998).

48. B. Toro, H. Palma-Fleming and J. Navarro. Chemosphere 55, 267, (2004).

49. K.Nomata, K.S. Kang, T. Hayashi, D. Matesic, L. Lockwood, C.C. Chang, J.E. Trosko, Cell Biol. Toxicol. 12, 69, (1996).

50. U.S.EPA. Carcinogenicity Assessment of Chlordane and Heptachlor/ Heptachlor Epoxide. Prepared by the Office of Health and Environmental Assessment, Carcinogen Assessment Group, Washington, DC. OHEA-C204 (1996). 